\title{
Change in awareness levels of cervical cancer among rural women after intervention by health education: a community-based study
}

\author{
G. Kalpana ${ }^{1}$, Keshav Gangadharan ${ }^{1 *}$, Pradeep S. ${ }^{1}$, Devivaraprasad M. ${ }^{2}$
}

\begin{abstract}
${ }^{1}$ Department of Obstetrics and Gynecology, PES Institute of Medical Sciences and Research, Kuppam, Andhra Pradesh, India

${ }^{2}$ Department of Community Medicine, PES Institute of Medical Sciences and Research, Kuppam, Andhra Pradesh, India
\end{abstract}

Received: 30 January 2020

Accepted: 07 February 2020

\section{*Correspondence:}

Dr. Keshav Gangadharan,

E-mail: drgkeshav@gmail.com

Copyright: ( ) the author(s), publisher and licensee Medip Academy. This is an open-access article distributed under the terms of the Creative Commons Attribution Non-Commercial License, which permits unrestricted non-commercial use, distribution, and reproduction in any medium, provided the original work is properly cited.

\section{ABSTRACT}

Background: Cervical cancer is the fourth most common cancer among women worldwide. The prevention and control of cervical cancer depends on awareness about the disease, screening procedures, and preventive measures. Objectives of this study was to assess the awareness levels on various aspects of cervical cancer among women aged 25-65 years, and to assess the impact of health education intervention among them.

Methods: This community-based interventional study was conducted for a period of 15 months among 250 women aged 25-65 years by cluster sampling method in a rural population. Data on all aspects of awareness about cervical cancer, i.e., risk factors, signs and symptoms, diagnosis and treatment and prevention were collected using a pretested semi-structured proforma. This was followed by a post-test 2 months after health education.

Results: Overall awareness for cervical cancer was found to be very poor among the study subjects in the pre-test. Awareness on risk factors, signs and symptoms, diagnosis and treatment, and prevention of cervical cancer was found to be $6 \%, 3.6 \%, 1.2 \%$, and $1.6 \%$ respectively. A significant increase in the knowledge level was found after health education.

Conclusions: As the awareness levels regarding the cervical cancer was poor among the study population, health education programme and campaigns, along with periodic screening is need of the hour to effectively prevent cervical cancer.

Keywords: Cervical cancer, Health education, Rural women

\section{INTRODUCTION}

Cervical cancer is the fourth most common cancer among women worldwide, with an estimated 560,505 new cases and 284,923 deaths in $2015 .{ }^{1}$ Around $85 \%$ of cervical cancer cases are reported from less developed regions. Because of poor access to screening and treatment services in these regions, cervical cancer accounts for $10 \%$ of all female cancer deaths. ${ }^{2}$ Similarly, in India, cervical cancer is one of the most common causes of cancer-related deaths. According to National Institute of cancer prevention and research, one woman dies of cervical cancer every 8 minutes in India. ${ }^{3}$

The most common symptoms present in cervical cancer are bleeding between periods, persistent back pain, bleeding after intercourse, urinary urgency, and unexplained weight loss. Infection with human papilloma virus (HPV), particularly HPV 16 and 18 strains cause $75 \%$ of cervical cancers globally. Other risk factors include having multiple sexual partners, early age of sexual intercourse, tobacco consumption, prolonged use 
of oral contraceptive pills, increased parity, and early age of giving birth. Prevention and control of cervical cancer depends on awareness about the disease, screening procedures, and preventive measures. ${ }^{4}$ Screening for cervical cancer is essential as the women often do not experience symptoms until the disease has advanced. ${ }^{5}$

\section{Objectives}

- To assess the awareness levels on various aspects of cervical cancer among women aged 25-65 years.

- To assess the impact of health education intervention among them.

\section{METHODS}

This community-based observational study was conducted in field practice area of PES Institute of Medical Sciences and Research, Kuppam, Andhra Pradesh between January 2018 and March 2019 for a period of 15 months.

Women aged 25-65 years formed the study population and a sample size of 250 was calculated based on the prevalence of awareness about cervical cancer as $25 \%$. Absolute precision of ' 7 ' and a design effect of ' 1.5 ' were considered for this study as cluster sampling method was applied to select the sample population, where every village was considered as a cluster. From each of these 20 such villages, houses with women aged 25-65 years were noted and around 10-15 such houses were randomly selected. One woman from each such house was interviewed, and this method was followed in every village till the required sample is met. Inclusion criteria were women aged 25-65 years, residing in the study area for at least one year, and those who were willing to participate in the study. Modified BG Prasad classification of socio-economic status was applied to categorize the participants based on the social class. ${ }^{6}$ In the pre-test, a pre-tested semi-structured proforma was used for data collection regarding demographic variables like age, educational status, marital status, etc., and on all aspects of awareness about cervical cancer, i.e., risk factors, signs and symptoms, diagnosis and treatment, prevention of cervical cancer. This was followed by health education by flip charts, by playing health educational videos etc. and this was further reinforced by a second time health education, given after one month. After 2 months, awareness levels were re-tested in posttest using a similar questionnaire as in the pre-test.

\section{Statistical analysis}

Data was entered into MS Excel 2007 version and further analyzed using SPSS version 20. For descriptive analysis, categorical variables were analyzed by using percentages and for inferential analysis, tests such as Chi-square test, and McNemar test was applied; $\mathrm{p}<0.05$ was considered as statistically significant.

\section{RESULTS}

The present study was conducted in rural areas of Kuppam Mandal, Chittoor district, Andhra Pradesh to find out the awareness among 250 rural women on various aspects of cervical cancer and the impact of health education among them.

Table 1: Socio-demographic details of the study subjects.

\begin{tabular}{|c|c|c|}
\hline Variable & $\begin{array}{l}\text { Number } \\
(\mathrm{n}=\mathbf{2 5 0})\end{array}$ & $\begin{array}{l}\text { Frequency } \\
(\%)\end{array}$ \\
\hline \multicolumn{3}{|l|}{ Age (in years) } \\
\hline $25-35$ & 105 & 57.6 \\
\hline $36-45$ & 71 & 22.8 \\
\hline $46-55$ & 50 & 18.4 \\
\hline $56-65$ & 24 & 01.2 \\
\hline \multicolumn{3}{|l|}{ Marital status } \\
\hline Unmarried & 06 & 02.4 \\
\hline Married & 236 & 94.4 \\
\hline Widowed/ Separated & 08 & 03.2 \\
\hline \multicolumn{3}{|l|}{ Type of family } \\
\hline Nuclear & 211 & 84.4 \\
\hline Joint/three-generation & 39 & 15.6 \\
\hline \multicolumn{3}{|l|}{ Education } \\
\hline Illiterate & 144 & 57.6 \\
\hline Primary & 57 & 22.8 \\
\hline Secondary/intermediate & 46 & 18.4 \\
\hline Graduate and above & 03 & 01.2 \\
\hline \multicolumn{3}{|l|}{ Occupation } \\
\hline Housewife & 219 & 87.6 \\
\hline Working & 31 & 12.4 \\
\hline \multicolumn{3}{|l|}{ Socioeconomic status } \\
\hline Class I & 18 & 07.2 \\
\hline Class II & 64 & 25.6 \\
\hline Class III & 66 & 26.4 \\
\hline Class IV & 73 & 29.2 \\
\hline Class V & 29 & 11.6 \\
\hline
\end{tabular}

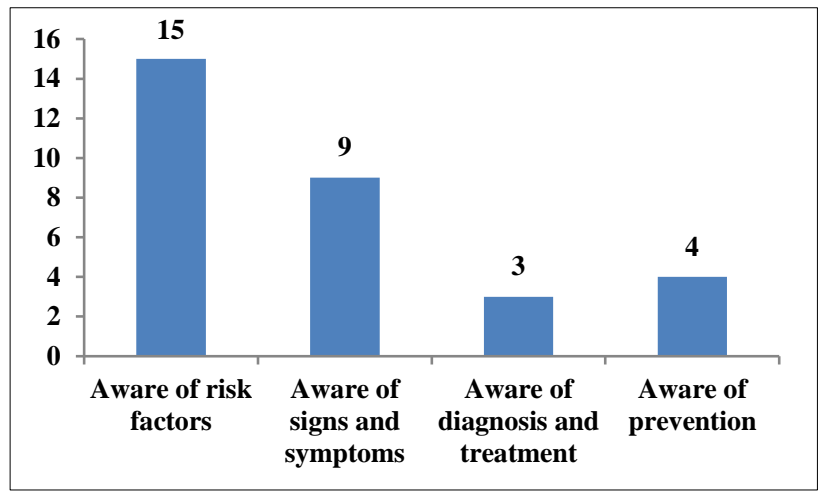

Figure 1: Awareness on several aspects of cervical cancer in the pre-test $(n=250)$.

Participants were of 25-35 years (57.6\%), Most (94.4\%) of them were married and $84.4 \%$ were from Nuclear 
families (Table 1). With regard to education, $18.4 \%$ had completed secondary level school or above, $22.8 \%$ had primary level and $57.6 \%$ were illiterates. Regarding occupation, $87.6 \%$ were housewives and 12.4 were working women. Participants belonged to five socioeconomic classes: Class I (7.2\%), Class II (25.6\%), Class III (26.4\%), Class IV (29.2\%), and Class V (11.6\%).

Table 2: Change in awareness of cervical cancer among the study subjects.

\begin{tabular}{|c|c|c|c|}
\hline \multirow{2}{*}{ Aspect of cervical cancer } & \multicolumn{2}{|l|}{ Phase of the study } & \multirow{2}{*}{ p value } \\
\hline & Before intervention & After intervention & \\
\hline \multicolumn{4}{|c|}{ Awareness on risk factors for cervical cancer } \\
\hline Present & $15(6.0)$ & $244(97.6)$ & \multirow{2}{*}{$<0.001^{*}$} \\
\hline Absent & $235(94.0)$ & $6(2.4)$ & \\
\hline \multicolumn{4}{|c|}{ Awareness on signs and symptoms of cervical cancer } \\
\hline Present & $9(3.6)$ & $246(98.4)$ & \multirow{2}{*}{$<0.001^{*}$} \\
\hline Absent & $241(96.4)$ & $4(1.6)$ & \\
\hline \multicolumn{4}{|c|}{ Awareness on diagnosis and treatment of cervical cancer } \\
\hline Present & $3(1.2)$ & $245(98.0)$ & \multirow{2}{*}{$<0.001^{*}$} \\
\hline Absent & $247(98.8)$ & $5(2.0)$ & \\
\hline \multicolumn{4}{|c|}{ Awareness on prevention of cervical cancer } \\
\hline Present & $4(1.6)$ & $247(98.8)$ & \multirow{2}{*}{$<0.001^{*}$} \\
\hline Absent & $246(98.4)$ & $3(1.2)$ & \\
\hline
\end{tabular}

(Percentages in the parenthesis) $(* \mathrm{p}<0.05$ is statistically significant).

Table 3: Factors significantly associated with change in awareness of cervical cancer.

\begin{tabular}{|c|c|c|c|}
\hline \multirow{2}{*}{ Significant factors } & \multicolumn{2}{|l|}{ Correct knowledge } & \multirow{2}{*}{ p value } \\
\hline & Before intervention & After intervention & \\
\hline \multicolumn{4}{|c|}{ Education versus correct knowledge on risk factors } \\
\hline Illiterate $(n=144)$ & $2(1.3)$ & $142(98.6)$ & \multirow{2}{*}{$0.001 *$} \\
\hline Literate $(n=106)$ & $139(12.2)$ & $103(97.1)$ & \\
\hline \multicolumn{4}{|c|}{ Education versus correct knowledge on signs and symptoms } \\
\hline Illiterate $(\mathrm{n}=144)$ & $0(0)$ & $142(98.6)$ & \multirow{2}{*}{$<0.001 *$} \\
\hline Literate $(\mathrm{n}=106)$ & $9(8.4)$ & $104(98.1)$ & \\
\hline \multicolumn{4}{|c|}{ Education versus correct knowledge on diagnosis and treatment } \\
\hline Illiterate $(n=144)$ & $0(0)$ & 141(97.9) & \multirow{2}{*}{$0.04 *$} \\
\hline Literate $(\mathrm{n}=106)$ & $3(2.8)$ & $104(98.1)$ & \\
\hline \multicolumn{4}{|c|}{ Occupation versus correct knowledge on risk factors } \\
\hline Housewife $(n=219)$ & $9(4.1)$ & $214(97.7)$ & \multirow{2}{*}{$0.003^{*}$} \\
\hline Working $(\mathrm{n}=31)$ & $6(19.4)$ & $31(100)$ & \\
\hline
\end{tabular}

(Percentages in the parenthesis) $(* \mathrm{p}<0.05$ is statistically significant).

Awareness on several aspects of cervical cancer was categorized into 4 parts: risk factors, signs and symptoms, diagnosis and treatment, and prevention of cervical cancer. Ten questions were given under risk factors, signs and symptoms, and diagnosis and treatment categories. Of these, those who were able to correctly answer minimum of five questions were considered to be aware of the topic, which was found to be $6 \%, 3.6 \%$, and $1.2 \%$ respectively. Similarly, for the prevention category, 5 questions given and those who were able to correctly answer minimum of three questions were considered to be aware (1.6\%). After intervention, by health education in the form of flip charts, video presentations and didactic lectures in the local language, there was a significant improvement in the awareness levels in all the aspects of cervical cancer $(\mathrm{p}<0.05)$ (Figure 1 and Table 2).

Thus, education was the main factor that was significantly associated with a change in the awareness levels regarding risk factors, signs and symptoms and diagnosis and treatment, and prevention of the disease. Though the illiterate group showed less knowledge before intervention, there was significant increase in the post-test $(\mathrm{p}<0.05)$. Similarly, occupation was another factor that was significantly associated with change in the awareness levels regarding risk factors. Though nonworking group showed less knowledge before intervention, there was significant increase in the posttest $(\mathrm{p}<0.05)($ Table 3$)$. 


\section{DISCUSSION}

The present study was conducted to determine the impact of health education on the awareness regarding cervical cancer among women aged 25-65 years in a rural community of Kuppam. Before the health education intervention, awareness of the participants on cervical cancer risk factors, signs and symptoms, diagnosis and treatment, and prevention was very poor. However, this awareness showed significant increase among them after health education $(\mathrm{p}<0.05)$.

In the present study, before the health education intervention, only 15 participants $(6.0 \%)$ were having awareness on cervical cancer risk factors. However, this awareness increased to $97.6 \%$ among the participants in the post-test, and difference was statistically significant. Awareness on risk factors like young age at first birth, multiple pregnancies, multiple pregnancies, human papilloma virus infection etc. will help women in adopting necessary precautionary measures, thus reducing the incidence of disease among them. Similarly, awareness for other aspects of cervical cancer like signs and symptoms, diagnosis and treatment, and prevention showed a significant improvement in the post-test. A study by Kumar et al showed that only $14.5 \%$ had awareness on screening. ${ }^{7}$ Similar findings were reported by Bathija et al for awareness about Pap smear. ${ }^{8}$ In contrast, in a study conducted by Shah V et al, majority (61\%), had knowledge of Pap smear as screening test. In a study done in Turkey, $62.4 \%$ had knowledge on at least one preventive measure. ${ }^{9,10}$

Lack of awareness and absence of symptoms were the main reason given by women for not undergoing screening. A study in Kerala study showed that almost three-fourths of the study population were aware of cervical cancer and its screening. ${ }^{11}$ According to studies done by Arunadevi V, and Prasad G on the knowledge about the epidemiology of cervical cancer, results showed that $38 \%$ of the respondents recognized that cervical cancer is the most common malignancy in gynecological cancers, while $28 \%$ thought that it is moderately common and $34 \%$ thought that it is least common, $36 \%$ were aware that it is the second most common gynaecological cancer leading to death. ${ }^{12}$

Education and occupation were significantly associated with change in the awareness levels about cervical cancer. This demonstrates the need for specific approaches in health education for different types of people in attaining the desired changes.

\section{CONCLUSION}

The level of knowledge of cervical cancer among women aged 25-65 years in rural areas was poor. A significant increase in the level of knowledge of cervical cancer regarding risk factors, signs, diagnosis and preventive methods among the population was found after health education in this study. Change in awareness levels regarding cervical cancer risk factors, signs and symptoms, prevention and diagnosis was significantly associated with the education and occupation of the study subjects. Implementing community-based awareness programs against cervical cancer is realistic, locally affordable and sustainable in low-income countries, which may save many lives over time and, importantly, will facilitate the integration of comprehensive programs when feasible. Adopting this strategy may provide one good example of how to achieve "good health at low cost". To inculcate safe lifestyle practices, awareness programs should be conducted more widely and frequently, particularly among those in the high-risk groups.

Funding: No funding sources

Conflict of interest: None declared

Ethical approval: The study was approved by the Institutional Ethics Committee

\section{REFERENCES}

1. Ferlay J, Soerjomataram I, Ervik M, Dikshit R, Eser S, Mathers C, et al, Bray F: GLOBOCAN 2012 v1.0. Cancer Incidence and Mortality Worldwide: IARC Cancer Base No. 11. Lyon, IARC;2013.

2. Sharma A, Kulkarni V, Bhaskaran U, Singha M, Mujtahedi S, Chatrath A, et al. Profile of cervical cancer patients attending Tertiary Care Hospitals of Mangalore, Karnataka: A 4 year retrospective study. J Nat Sci Biol Med. 2017;8:125-9.

3. Sathiyalatha S, Hemavathy V, Vijayalakshmi R. Cervical cancer kills one Indian woman every 7 minutes. Int J Innov Res Dev. 2015;4:132-4.

4. Kaarthigeyan K. Cervical cancer in India and HPV vaccination. Indian $\mathrm{J}$ Med Paediatr Oncol. 2012;33:7-12.

5. Mishra GA, Pimple SA, Shastri SS. An overview of prevention and early detection of cervical cancers. Indian J Med Paediatr Oncol. 2011;32:125.

6. Vasudevan J, Mishra AK, Singh Z. An update on B. G. Prasad's socioeconomic scale: May 2016. Int J Res Med Sci. 2016;4:4183-6.

7. Harsha Kumar HN, Tanya S. A study on knowledge and screening for cervical cancer among women in Mangalore city. Ann Med Health Sci Res. 2014;4(5):751-6.

8. Bathija GV, Mallesh S, Gajula M. A study on awareness of cervical cancer amongwomen of reproductive age group in urban slums of old Hubli, Karnataka, India. Int $\mathbf{J}$ Community Med Public Health. 2016;3:2579-83.

9. Shah V, Vyas S, Singh A, Shrivastava M. Awareness and knowledge of cervical cancer and its prevention among the nursing staff of a tertiary health institute in Ahmedabad, Gujarat, India. E-cancer. 2012;6(270):1-6.

10. Temel AB, Dağhan Ş, Kaymakçı Ş, Dönmez RÖ, Arabacı Z. Effect of structured training programme 
on the knowledge and behaviors of breast and cervical cancer screening among the female teachers in Turkey. BMC Women's Health. 2017;17(1):123.

11. Aswathy S, Quereshi MA, Kurian B, Leelamoni K. Cervical cancer screening: current knowledge and practice among women in a rural population of Kerala, India. Indian J Med Res. 2012;136(2):20510.
12. Arunadevi V, Prasad G. Knowledge and awareness of cervical cancer among women in rural India. Int $\mathbf{J}$ Cur Res Rev. 2015;7(21):29-32.

Cite this article as: Kalpana G, Gangadharan K, Pradeep S, Devivaraprasad M. Change in awareness levels of cervical cancer among rural women after intervention by health education: a community-based study. Int J Reprod Contracept Obstet Gynecol 2020;9:960-4. 